УДК 373.2.015.31:51

DOI:

Оксана Гевко, кандидат педагогічних наук, доиент кафедри загальної педагогіки та дошкільної освіти Дрогобииького державного педагогічного університету імені Івана Франка Романія Дутко, магістр дошкільної освіти Дрогобицького державного педагогічного університету імені Івана Франка

\title{
ПЕДАГОГІЧНІ ШЛЯХИ ЛОГІКО-МАТЕМАТИЧНОГО РОЗВИТКУ ДІТЕЙ СТАРШОГО ДОШКІЛЬНОГО ВІКУ
}

У статті на основі аналізу психолого-педагогічної літератури розкрито наукові підходи до трактування понять “логічне мислення”, “логіко-математичне мислення”. Визначено структуру логічного мислення, компонентами якої є логічні операції (порівняння, аналіз, синтез, класифікація, узагальнення та ін.). Визначено компоненти у структурі логіко-математичного розвитку особистості (високий рівень виконання логічних операцій, конструктивність, адекватність, гнучкість, економічність і самостійність мислення, характер зв'язку наочно-дійового, наочно-образного логічного мислення тощо). 3'ясовано ефективні засоби логіко-математичного розвитку дітей дошкільного віку: проведення логіко-математичних занять, планування осередків (пізнавального, художньо-перетворювального, фізкультурно-оздоровчого, комунікативного та емоційно-рефлексивного), пізнавально-дослідницька діяльність, використання ігор, вправ, логікоматематичних задач, ігрових та проблемних ситуацій та завдань, театралізованої діяльності, конструювання, використання художнього слова, народної педагогіки та математики, пошуково-дослідницька діяльність дітей дошкільного віку.

Ключові слова: логічне мислення; логіко-математичний розвиток; обчислення; лічба; величина; вимірювання; серіація; класифікаџія; діти старшого дошкільного віку.

Jim. 4.

Oksana Hevko, Ph.D.(Pedagogy), Associate Professor of the General Pedagogy and Preschool Education Department, Drohobych Ivan Franko State Pedagogical University

Romaniya Dutko, Master Student of the Preschool Education Department Drohobych Ivan Franko State Pedagogical University

\section{PEDAGOGICAL WAYS OF LOGIC AND MATHEMATICAL DEVELOPMENT OF SENIOR PRESCHOOL CHILDREN}

In the article, the scientific approaches to the interpretation of the concepts: "logical thinking", "logical and mathematical thinking" are revealed based on the analysis of the psychological and pedagogical literature. The structure of logical thinking, the components of which are logical operations (comparison, analysis, synthesis, classification, generalization, etc.) is defined. The components of the structure of logical and mathematical development of personality (high level of execution of logical operations, constructiveness, adequacy, flexibility, economy and independence of thinking, nature of communication of visual-effective, visual-logical thinking, etc.) are determined.

An emphasis is placed on the psycho-emotional component of logical and mathematical thinking, its emotional positive influence on the course of various mental processes (perception, memory, imagination, and thinking) and in general, on personality formation.

The effective means of logical and mathematical development of preschool children are found out: conducting logic and mathematical classes, planning centers (cognitive, artistic-transformative, physical-health-improving, communicative and emotional-reflexive), cognitive-research activity, the use of games and situations, theatrical activities, a design, the use of artistic words (poems, tasks, stories, jokes), folk pedagogy and mathematics (fairy tales, riddles, sayings), problem situations and the task, the task of search elements, didactic games and exercises, alternative methods of teaching mathematics, problem solving situations and tasks of search and research activities by preschool children, joke tasks, puzzle tasks, fairy story making tasks.

Keywords: logical thinking; logical and mathematical developmen; calculus; a number; a size; measurement; seriation; classification; children of senior preschool age.

П остановка проблеми. Серед проблем сучасного етапу розвитку суспільства можна виділити проблему логіко-математичного розвитку дітей дошкільного віку, зокрема старшого, адже сформоване логіко-математичне мислення сприяє сучасній особистості аналізуванню різноманітних процесів, що передбачає відхід від 


\section{ПЕДАГОГІЧНІ ШЛЯХИЛОГІКО-МАТЕМАТИЧНОГО РОЗВИТКУ ДІТЕЙ СТАРШОГО ДОШКІЛЬНОГО ВІКУ}

загальноприйнятих стереотипів, розроблених алгоритмів вирішення життєвих нестандартних ситуацій та проблем, але й коригування та адаптація особистої діяльності у постійно змінюваних умовах життя.

Аналіз наукових досліджень стверджує появу логіко-математичного мислення особистості ще у дошкільному віці та необхідність його цілеспрямованого формування у старшому дошкільному віці через підвищення ініціативності та активізацію діяльності дошкільника. Адже саме в старшому дошкільному віці наочно-дійове мислення дитини доповнюється та частково заміщується наочно-образним, а відтак старший дошкільник при прийнятті вирішень задач та завдань дедалі частіше застосовує так зване міркувальне логіко-математичне мислення.

Формування логіко-математичної компетентності у дошкільних навчальних закладах для наступного вивчення математики в загальноосвітній школі забезпечує засвоєння особистістю системних математичних знань, умінь і навичок, необхідних у повсякденному житті та достатніх для оволодіння іншими предметами і забезпечення наступності із основною ланкою школи.

Сучасні програми розвитку дітей дошкільного віку, Базовий компонент дошкільної освіти серед завдань всебічного розвитку підростаючої особистості дошкільника значне місце приділяють логіко-математичному розвитку і математичній підготовці дітей дошкільного віку. В цих документах наголошено на потребі формування не лише певних математичних уявлень та понять, а й необхідності логіко-математичного розвитку, що сприятиме подальшому прийняттю дошкільником нової соціальної ролі школяра, довільної ініціативної поведінки, продуктивної уяви, сприятиме подальшому розвитку пізнавальної сфери, допитливості, вмінню будувати речення, порівняльних конструкцій, умінню виокремлювати, класифікувати, аналізувати, синтезувати [2, 140], узагальнювати та робити висновки, вмінню і прагненню вчитися логічно мислити у життєвих ситуаціях.

Аналіз останніх досліджень і публікацій. У наукових дослідженнях Л. Виготського, О. Леонтьєва, Н. Менчинської, А. Усової, К. Щербакової обгрунтовано психолого-педагогічні підходи до здатності виявляти дітьми дошкільного віку суттєвих зв'язків дійсності, усвідомлення ними нескладних за змістом наукових понять, пояснюючи доступність цих понять через залучення дітей до предметно-чуттєвої пізнавальної діяльності (Л.Білоусько, Л. Венгер, О.Гевко, О. Запорожець). Вивченням формування у дошкільників операцій лічби займалися О. Грибанова, М. Дудник, Г. Леушина, Н. Менчинська, Л. Метліна. Особливості сприйняття дошкільниками форм об'єктів, розрізнення геометричних фігур розглядали 3. Богуславська, Н. Ізвєкова, К. Крутій, Т. Науменко; формування просторових уявлень, а також уявлень про величину предметів розглянуто в працях Л. Артемової, А. Богуш, Н. Гавриш, Н. Голота, К. Кібальна. В. Котирло; розробці оптимальних форм і методів навчання, спрямованих на розвиток логічного, творчого мислення дітей дошкільного віку в процесі формування елементарних математичних понять, практичній апробації у дошкільній освіті, що рекомендовано у методичних посібниках О. Кобрій, Г. Леушиної, О. Розіної, І. Светлової, В. Сухар, Н. Тарнавської, М. Трайкун, К. Щербакової та ін.). Метою навчання на заняттях в дитячому садку є засвоєння дитиною заданих програмою знань і умінь на певному віковому етапі. Можливості та особливості формування у дітей дошкільного віку логіко-математичних уявлень, набуття ними навичок виконувати елементарні дії та операції є основою наступного шкільного навчання, готовності до активної осмисленої життєдіяльності розглянуто у дослідженнях О.І. Гевко, Г.В. Белошистої, Л.І. Зайцевої, Т.В. Коваленка, Г.М. Леушиної, Т.І. Пантюк, Л.С. Плетеницької, А.А. Столяра, О.В. Шаран, К.Й. Щербакової. Поняття “здібності” було об'єктом дослідження багатьох науковців, зокрема, Л.В. Білоусько, М.М. Дудник, О.Г. Ковальова, К.К. Платонова, Б.М. Теплова та ін.

Метою дослідження $€$ обгрунтування педагогічних шляхів логіко-математичного розвитку старших дошкільників та окреслення можливостей використання результатів дослідження у науково-практичній діяльності вихователя.

Виклад основного матеріалу. Поняттям логіко-математичний розвиток означуються якісні зміни в пізнавальній діяльності дитини дошкільного віку, що стимулюються розвитком елементарних математичних уявлень, умінням здійснювати логічні операції. Логікоматематичний розвиток особистості передбачає: активізацію пізнавальної діяльності через розширення спектру пізнавальних дій; підготовка до майбутньої навчальної діяльності у закладах загальної середньої освіти: здатність самостійної діяльності, здійснення адекватного самооцінювання та самоконтролю тощо; розвиток творчого конструктивного мислення особистості, умінь послідовно та логічно робити висновки у 


\section{ПЕДАГОГІЧНІ ШЛЯХИЛОГІКО-МАТЕМАТИЧНОГО РОЗВИТКУ ДІТЕЙ СТАРШОГО ДОШКІЛЬНОГО ВІКУ}

предметно-ігровому середовищі, через дидактичні, логічні ігри тощо; зацікавлення дошкільників логіко-математичною діяльністю та виховання потреби легко здійснювати елементарні логіко-математичні операції у власній життєдіяльності та іграх.

Логічне мислення вміщує в собі здатність мислити точно і послідовно, виділяючи суттєві ознаки предмету, уміння здійснення порівняння предметів та понять, уміння здійснювати теоретичний аналіз та узагальнення, не допускаючи протиріч у своїх міркування та вміння викривати логічні помилки, робити висновки.

Логічне мислення формується на основі образного та є вищою стадією розвитку мислення особистості. Розвинуте в особистості логічне мислення сприяє прийняттю правильного рішення без допомоги досвіду та інтуїції, спонукає аналізувати явища і предмети, виділяти в них головне, послідовно міркувати, систематизувати, узагальнювати, робити висновки.

Багатоаспектність, комплексність та складність поняття “логіко-математичний розвиток” визначається взаємозалежністю та взаємообумовленістю елементарних уявлень про кількість, форму, величину, простір, час, властивості цих параметрів, їх співвідношень, що необхідні для формування в особистості життєвих і наукових понять, здійснення розумових дій $[4,59$ $-61]$.

Логіко-математичний розвиток, спрямований на особистість дошкільників, сприяє їм робити узагальнені, згорнуті, гнучкі й обернені асоціації, усвідомлювати певні системи, взаємозалежності тощо. Логіко-математичний розвиток передбачає формування у дітей дошкільного віку:

- здатності до використання числової та знакової символіки;

- вміння встановлювати взаємозв'язки та співвідношення між математичними поняттями;

- встановлення кількісних відношень, розрізнення просторових форм, порівняння величин;

- здатності до логічних міркувань та узагальнень;

- здатності здійснювати доведення та обгрунтовувати висновки;

- нешаблонності, гнучкості мислення;

- здатності до логічності та алгоритмізації, що скорочує процес міркувань;

- подолання стереотипів, стандартизації дій;

- здатності до переходу від прямого до оберненого ходу думки;

- здатності до змістового усвідомлення математичного матеріалу, виокремлення мало суттєвих змін із стандартних, схожих реальних ситуацій.

Формуванням у дітей дошкільного віку елементарних логіко-математичних уявлень передбачає ознайомлення дошкільників із формою, величиною, навчання їх рахувати та обчислювати, просторової та часової орієнтації. У Базовому компоненті дошкільної освіти $[1,12]$, означується логіко-математичний розвиток дитини як якісні зміни у мисленні дошкільника через удосконалення умінь здійснення як математичних, так і логічних операцій, тобто необхідність та доведення до автоматичності здійснення елементарних обчислень та вимірювань, класифікації та серіації. Такий розвиток є основою логіко-математичної компетентності дитини дошкільного віку, основними складовими лініями якої є: логічна, тобто уміння міркувати, здійснювати мислительні операції, а також математична - формування елементарних математичних уявлень.

Під компетентністю розуміють усвідомленість, знання, авторитетність у будь якій галузі. Логікоматематична компетентність включає в себе: здійснення найпростіших усних обчислень та поступове ускладнення виконуваних дій; класифікації предметів, множин, їі елементів, геометричних фігур за якісними та кількісними ознаками та характеристиками; вимірювань; розташування у просторі та часі; виконання серіації за величиною, масою, об'ємом; вимірювання кількості, довжини, ширини, висоти, об'єму, маси, часу; розв'язування арифметичних і логічних завдань та задач; виявлення інтересу до логіко-математичної діяльності тощо. При цьому важливо не стільки наявність логікоматематичних знань, скільки здатність розсудливо поводитися, використовувати ці знання у різноманітних життєвих ситуаціях, здійснювати ініціативність, самостійність та послідовність міркувань, проявляти гнучкість мислення у нестандартних ситуаціях, здійснювати не тільки високу пізнавальну активність, а й проявляти логічність та кмітливість.

Логіко-математична компетентність складається 3 трьох основних компонентів: мотиваційний, змістовий та дійовий:

- мотиваційний вміщує внутрішню мотивацію, інтереси.

- змістовий компонент включає комплекс математичних знань, умінь та навичок.

- дійовий компонент компетентності охоплює навички навчальної діяльності: самостійність, самооцінювання, здійснення самоконтролю.

У Базовому компоненті дошкільної освіти 


\section{ПЕДАГОГІЧНІ ШЛЯХИЛОГІКО-МАТЕМАТИЧНОГО РОЗВИТКУ ДІТЕЙ СТАРШОГО ДОШКІЛЬНОГО ВІКУ}

“логіко-математична компетентність” дошкільників визначається як уміння класифікувати предмети, геометричні фігури, множини; здійснювати серіацію за масою, величиною, об'ємом, розташовувати предмети у просторі й часі; уміння обчислювати та вимірювати кількість елементів, їх висоту, довжину, ширину, об’єм, масу, час тощо [1, 190].

Ми виділили педагогічні умови формування логіко-математичної компетентності:

- врахування у змісті дошкільної освіти логічного підгрунтя формування наступних елементарних математичних понять. Що мають сприяти послідовній посильній цілеспрямованій пізнавальній діяльності дітей дошкільного віку;

- осягнення змісту та особливостей понять “число”, “форма”, “величина”,;

- співвіднесення кількісних і якісних характеристик досліджуваних предметів із конкретними математичними поняттями;

- виокремлення та узгодження певних предметів за встановленими математичними характеристиками, дослідження та доведення причинно-наслідкових зв'язків, обгрунтування висновків через здійснення порівняння, класифікації предметів;

- здійснення математичних узагальнень через наочно-образну, предметно-практичну, абстрактнологічну діяльність 3 предметами;

- здійснення операцій із множинами предметів;

- предметне діяльнісно-дійове засвоєння логікоматематичних понять;

- самостійне набуття дошкільників практичного досвіду засобами експериментування з множиною предметів;

- усвідомлення якісних та кількісних ознак множин предметів та співвіднесення їх iз класифікацією.

Під поняттям логіко-математичного розвитку ми розуміємо якісні зміни в пізнавальній діяльності дитини, що відбуваються внаслідок розвитку математичних умінь і пов'язаних з ними логічних операцій $[3,22]$.

Інтенсифікують логіко-математичний розвиток дітей дошкільного віку розробка вихователями цілісного комплексу завдань, вправ та дидактичних ігор спрямовані на формування та розвиток певного математичного поняття; виділення ознак предметів (колір, величина, матеріал, форма, розмір тощо); логічного перебігу подій, обчислень, формування прийомів розумових дій (аналізу, синтезу, узагальнення, класифікаціі); порівняння предметів за спільними та відмінними характеристиками; об'єднання та розмежування групи предметів за суттєвими характеристиками та ознаками.
Ми визначили шляхи логіко-математичного розвитку, які передбачають вибір найефективніших i найоптимальніших форм роботи 3 дітьми дошкільного віку. Серед ефективних засобів логіко-математичного розвитку дошкільників виділяємо проведення логіко-математичних занять, планування осередків (пізнавального, фізкультурно-оздоровчого, художньо-перетворювального, комунікативного та емоційно-рефлексивного), пізнавально-дослідницька діяльність, використання ігор, ігрових ситуацій, театралізованої діяльності, конструювання, використання художнього слова (віршовані задачі, задачі-розповіді, задачі-жарти), народну педагогіку (казки, загадки, прислів'я), проблемні ситуації та завдання, завдання 3 елементами пошуку, дидактичні ігри і вправи, нетрадиційні методи навчання математики: проблемні ситуації та завдання, пошуководослідницька діяльність дітей дошкільного віку, задачі-жарти, задачі-загадки, задачі з казковим сюжетом.

Висновки. Різноплановість, урізноманітнення, послідовність формування логіко-математичного розвитку спрямовує та інтегрує весь навчальновиховний процес у закладах дошкільної освіти та спрямовує життєдіяльність дітей дошкільного віку (перегляд, опис, лічба, порівняння, класифікація та серіація предметів, використання засобів образотворчого мистецтва: малювання, ліплення, вирізування та витинання, аплікації, конструювання, використання настільних конструкторських ігор: втулок, конструкторів, лего, кубиків, пірамідок, звичайних блоків та блоків Дьєнеша; використання ігор - головоломок, лабіринтів, змійок, кубіків, карток, планшеток; виготовлення схем, простих та складних планів, доріжок, моделей, макетів, використання творчих ігор тощо).

\section{ЛІТЕРАТУРА}

1. Базовий компонент дошкільної освіти в Україні. Дошк. виховання, 1999. № 1. С. 6-19.

2. Скотна М. Математична освіта дошкільників у Польщі. Молодь іринок. №12(107), 2013. С.137-142.

3. Старченко В. Логіко-математичний аспект дошкільної освіти. Дошкільне виховання. 2005. № 7 . С. 22-23.

4. Татаринова С.О. Логіко-математична компетентність дітей старшого дошкільного віку. Актуальні проблеми дошкільної та початкової освіти в сучасних умовах : зб. наук.праць. Херсон, 2004. C. 59-61.

\section{REFERENCES}

1. Bazovyi komponent doshkilnoi osvity v Ukraini (1999). [The basic component of pre-school 
education in Ukraine]. Preschool education, no. 1, pp. 6-19. [in Ukrainian].

2. Skotna, M. (2013). Matematychna osvita doshkilnykiv u Polshchi [Mathematical education of preschool children in Poland]. Youth and market, no.12(107), pp.137-142. [in Ukrainian].

3. Starchenko, V. (2005). Lohiko-matematychnyi aspekt doshkilnoi osvity [Logic-mathematical aspect of preschool education]. Preschool education, no. 7, pp. 22-23. [in Ukrainian].

4. Tatarynova, S.O. (2004). Lohiko-matematychna kompetentnist ditei starshoho doshkilnoho viku [Logical and mathematical competence of preschool children]. Actual problems of preschool and primary education in modern conditions, Kherson, pp. 59-61. [in Ukrainian].

Стаття надійшла до редакції 19.08.2019

УДК 78.071.2:784.4(477)

DOI:

Лідія Федоронько, кандидат мистецтвознавства, доцент кафедри музикознавства та фортепіано

Дрогобицького державного педагогічного університету імені Івана Франка

\section{ВИКОНАВСЬКА РЕКОНСТРУКЦІЯ ОБРЯДІВ ЯК ОДИН 3 МЕТОДІВ ТРАНСМІСІЇ НАРОДНОЇ МУЗИЧНОЇ ТРАДИЦІї}

У статті висвітлено особливості реконструкиії обряду обжинок як одного з механізмів трансмісії фольклору. Проаналізовано всі існуючі публікації та архівні матеріали, в яких зафіксовано локальний варіант обжинок с. Нагуєвичі Дрогобиџького району. На чій основі продемонстровано можливість відтворення обряду у науково-виконавській інтерпретації, щуо дає можливість мінімалізувати стильові втрати через вторинну форму виконання.

Ключові слова: музичний фольклор; трансмісія фольклору; реконструкиія обряду; пісенні наспіви; народновиконавська манера.

Jim. 8.

Lidiya Fedoronko, Ph.D. (Art Studies), Associate Professor of the Musicology and Piano Department Drohobych Ivan Franko State Pedagogical University

\section{EXECUTIVE RECONSTRUCTION OF RITES AS ONE OF THE TRANSMISSION METHODS OF THE NATIONAL MUSICAL TRADITION}

The tradition remains relevant as a law of continuity, without which there can be no development of culture. In a globalized world, there is a threat of folklore disappearance in its local styles and variants. Therefore, it is necessary to find ways of the restoration and preservation of folk culture, in particular rites that occupy an important place in the genre system of Ukrainian folklore.

Ritual folklore is closely connected with the environment of existence, with the way of life of the community, the level of its economic and production status. With the change of these factors, the ritual sphere is changing or fading. One of the factors preventing the complete disappearance of local variants is the reconstruction of ceremonies, the most important components of which, besides composition, can be called verbal-musical element.

Based on existed publications and archival materials, a reconstruction of the reaping rites of village Nahuyevychi, Drohobych district (ethnographic district - Boyko Pidhirya) was done. The basic methodical techniques, which allow preserving the local style as much as possible, are derived and described. This is primarily due to the vocal and instrumental manner of execution, and the use of ethnographic elements.

Reproduction of the rite lives in the form of reconstruction, using fixed forms of conservation, makes it possible to actualize interesting patterns of local folklore in the new conditions.

Keywords: musical folklore; transmission of folklore; reconstruction of the rite; singing songs; folk-style manner.

П остановка проблеми. Сьогодні, в епоху глобалізації, яка стрімко набирає обертів в Україні, особливо гостро постає питання збереження традиції та ії місця у культурі. В умовах дискусії про консервативну i модерну складову в структурі останньої залишається актуальним розуміння традиції як передачі досвіду, звичаїв, культурних надбань із покоління в покоління, як закон спадкоємності, без якої не може бути розвитку культури. Можна згодитися зі словами Едварда Шилза, що традиція, якщо ії визнано, не менш жива й важлива 